\title{
High reliance on a diet of Moose (Alces americanus) by Eastern Coyotes (Canis latrans var.) in Cape Breton Highlands National Park, Nova Scotia, Canada
}

\author{
Jason W.B. Power ${ }^{1,2 *}$, Michael J. Boudreau ${ }^{2}$, Erich M. Muntz ${ }^{3}$, and Soren \\ BONDRUP-NIELSEN ${ }^{1}$ \\ ${ }^{1}$ Department of Biology, Acadia University, Wolfville, Nova Scotia B4P 2R6 Canada \\ ${ }^{2}$ Current address: Nova Scotia Department of Lands and Forestry, Wildlife Division, 136 Exhibition Street, Kentville, Nova \\ Scotia B4N 4E5 Canada \\ ${ }^{3}$ Cape Breton Highlands National Park of Canada, P.O. Box 158, Cheticamp, Nova Scotia B0E 1H0 Canada \\ *Corresponding author: Jason.WB.Power@novascotia.ca
}

Power, J.W.B., M.J. Boudreau, E.M. Muntz, and S. Bondrup-Nielsen. 2019. High reliance on a diet of Moose (Alces americanus) by Eastern Coyotes (Canis latrans var.) in Cape Breton Highlands National Park, Nova Scotia, Canada. Canadian Field-Naturalist 133(4): 329-331. https://doi.org/10.22621/cfn.v133i4.2138

\begin{abstract}
Eastern Coyote (Canis latrans var.) scats were collected along transects in Cape Breton Highlands National Park, Nova Scotia, Canada, from May 2012 to August 2013 to determine diet. Based on 294 scats, Moose (Alces americanus) remains made up the highest percentage by volume in scats during fall, winter, and spring. During the summer, Moose remains were found in over $30 \%$ of scats $(18 \%$ by volume), although fruit and berries were more commonly found. No other study has documented such high annual use of Moose. As there was no evidence that the consumed Moose were killed by Coyotes, presumably Coyotes scavenged Moose that had died of natural causes.
\end{abstract}

Key words: Eastern Coyote; Canis latrans var.; diet; Moose; Alces americanus; Cape Breton Highlands National Park

Eastern Coyotes (Canis latrans var.) were first recorded in Cape Breton Highlands National Park (CBHNP; Figure 1), Nova Scotia, Canada, in 1980 (E.M.M. pers. obs.). A high level of coyote-human aggressive encounters, including a human fatality (E.M.M. pers. obs.), resulted in the park initiating a study of the ecology of Coyotes within its boundaries. One aspect of this study was to understand their diet.

Coyotes typically exhibit a generalist diet (Young and Jackson 1951; Bekoff 1977; Prugh 2005; Lukasik and Alexander 2011) adjusting to seasonal availability of prey and other food sources (Patterson et al. 1998; Lukasik and Alexander 2011). Food selection ranges from preying on small mammals, such as rodents and lagomorphs, to large ungulates, livestock, or pets, as well as foraging for fruit, eating garbage, and scavenging (i.e., Bowyer et al. 1983; Fedriani et al. 2001; Lukasik and Alexander 2011). Eastern Coyotes have been known to prey effectively on adult White-tailed Deer (Odocoileus virginianus; Parker 1986; Patterson and Messier 2000) and, more recently, they have been documented killing adult Moose (Alces americanus) in Ontario (Benson and Patterson 2013). Here, we report on an unusually high reliance on a diet of Moose by Eastern Coyotes year round in CBHNP.

From May 2012 to August 2013, scats were collected every three weeks from $212-\mathrm{km}$-long transects randomly selected along established paths and trails throughout CBHNP (Figure 1). Percentage by volume for each prey remain was determined using the pointframe method (Chamrad and Box 1964) after scats were washed to retain hair and bones and other hard material and dried. A Kruskal-Wallis test (R Studio, version 0.98.490; $R$ version 3.0.2 reports $\chi^{2}$ ) was used to test for differences in prey remains among calendar seasons.

In total, 294 Coyote scats were collected along 966 cumulative $\mathrm{km}$ of trail transects. Dietary analysis of these scats indicated that Moose, fruit/berries, and Snowshoe Hare (Lepus americanus) made up the highest percentage of volume by season (Table 1). 


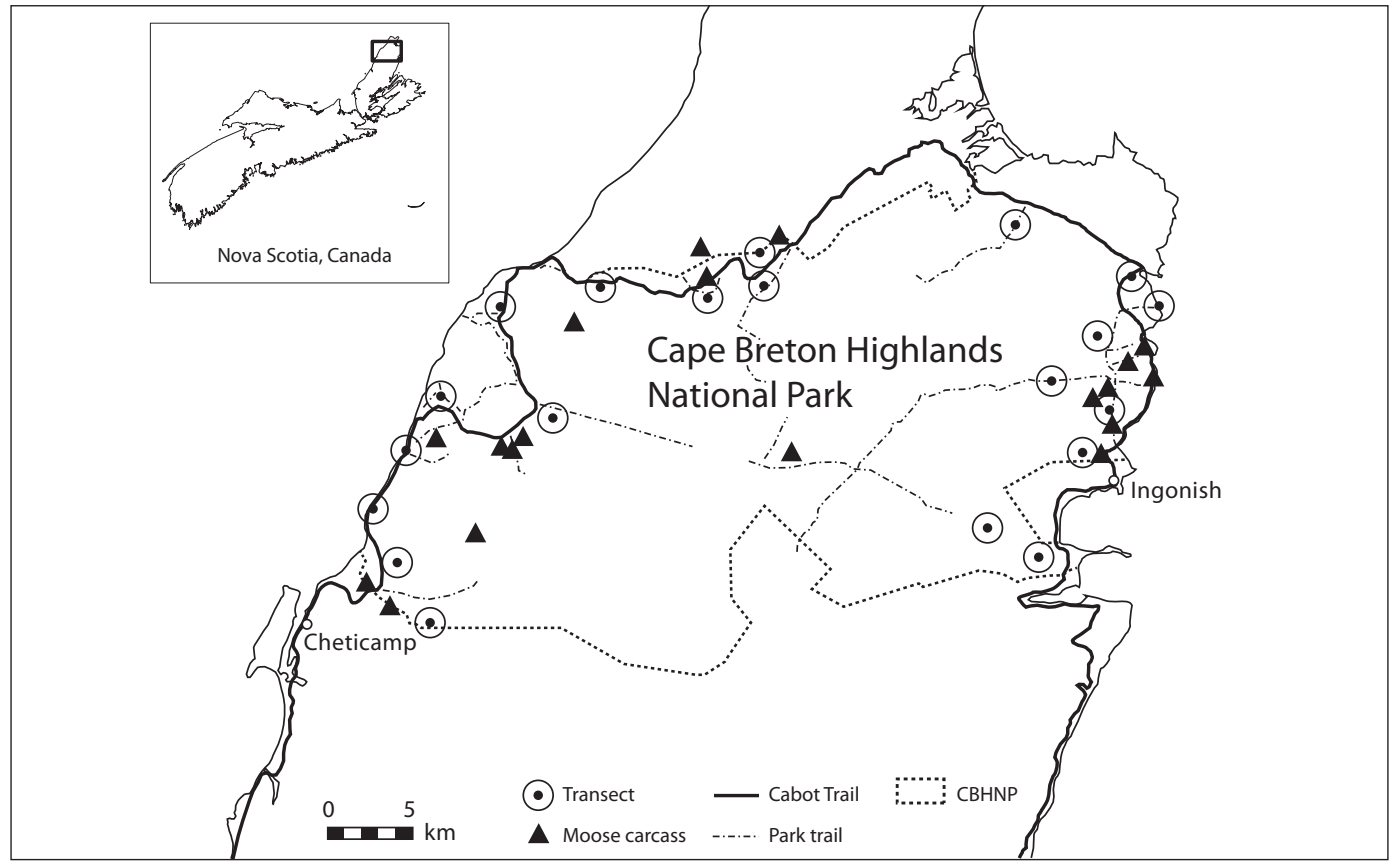

Figure 1. Locations of scat transects and Moose (Alces americanus) carcasses found between May 2012 and August 2013 in Cape Breton Highlands National Park.

Overall, Moose was the most common food by volume found in Coyote scats (over 70\% during spring and winter), followed by fruit/berries (fall 29\%, summer 56\%) and Snowshoe Hare (winter 25\%). Small mammals ( $23 \%$ fall), birds ( $9 \%$ fall), and deer $(8 \%$ spring) were less common.

While opportunistically back tracking Coyotes (57 tracks for a total of $109 \mathrm{~km}$ ) in winter, we found 19 Moose carcasses, all female ranging from 1.5 to 10.5 years old (aged by analyzing tooth pattern of lower jaw; Figure 1). None of the carcasses was located on or near scat transects. These carcasses had been scavenged by Coyotes; there was no evidence that Coyotes had killed any of these Moose.
These results indicate that Eastern Coyotes in CBHNP have a generalist diet with a high reliance on Moose. Studies in eastern Maine (Litvaitis and Harrison 1989), northwestern Wyoming (Dowd and Gese 2012), southeastern Quebec (Richer et al. 2002), western Maine (Major and Sherburne 1987), and New Brunswick (Dumond et al. 2001) have found Moose to make up a smaller proportion of the diet of Coyotes. Only in eastern Quebec did Boisjoly et al. (2010) report a high frequency of 51\% Moose in scats. Our study documents the highest percentage by volume of Moose in scats of Eastern Coyotes in CBHNP during the winter $(71 \%)$.

At the time of this study, Moose were likely the

TABLE 1. Analysis of prey remains identified from 294 scats of Eastern Coyote (Canis latrans var.) collected on trail transects in Cape Breton Highlands National Park, Nova Scotia, from May 2012 through August 2013.

\begin{tabular}{lcccccc}
\hline \hline & \multicolumn{3}{c}{$\%$ prey by volume (mean \pm SD) in each season* } & \\
\cline { 2 - 5 } Dietary remains & $\begin{array}{c}\text { Fall } \\
(n=40)\end{array}$ & $\begin{array}{c}\text { Winter } \\
(n=80)\end{array}$ & $\begin{array}{c}\text { Spring } \\
(n=64)\end{array}$ & $\begin{array}{c}\text { Summer } \\
(n=110)\end{array}$ & $\chi^{2}$ & $P$ \\
\hline Moose (Alces americanus) & $23.3 \pm 39.4$ & $71.2 \pm 44.5$ & $70.9 \pm 44.5$ & $18.0 \pm 35.8$ & 78.98 & 0.000 \\
White-tailed Deer (Odocoileus & - & $1.2 \pm 11.3$ & $7.8 \pm 27.0$ & - & 13.99 & 0.003 \\
virginianus) & & & & & \\
Snowshoe Hare (Lepus americanus) & $16.2 \pm 34.6$ & $24.8 \pm 42.2$ & $18.1 \pm 37.5$ & $11.8 \pm 30.4$ & 3.52 & 0.317 \\
Bird & $8.6 \pm 24.1$ & $0.9 \pm 5.8$ & $1.6 \pm 12.5$ & $1.9 \pm 6.4$ & 19.76 & 0.000 \\
Small mammal & $22.9 \pm 39.6$ & $1.9 \pm 12.1$ & $1.6 \pm 12.1$ & $12.0 \pm 27.6$ & 33.49 & 0.000 \\
Fruit & $29.1 \pm 41.9$ & - & - & $56.3 \pm 43.1$ & 147.20 & 0.000 \\
\hline \hline
\end{tabular}

*Fall = 22 September to 20 December, winter = 21 December to 19 March, spring = 20 March to 20 June, summer $=21$ June to 21 September. 
most biomass-rich food source available to Coyotes, especially in the highlands. Moose density in the highlands of CBHNP is typically high, with well over 1000 individuals in the park (Bridgland et al. 2007), although no estimate of Moose density was available during our study period. Gray Wolves (Canis lupus) in western Quebec were observed feeding on single Moose carcasses for up to 23 days (Messier and Crête 1985); thus, a Moose carcass could likely sustain a Coyote pack for several weeks as a protein- and energy-rich food source. Furthermore, less energy is likely expended scavenging a Moose carcass during winter and spring months compared with hunting small mammals. Cyclical lows of the Snowshoe Hare population during this study (E.M.M. pers. obs.) may have contributed to the primary occurrence of Moose in Coyote scats. Coyotes in CBHNP may rely on Moose carcasses because of their apparent availability and the lack of other prey, such as Snowshoe Hare, a common food source of Coyotes in other parts of Nova Scotia (Patterson et al. 1998).

\section{Literature Cited}

Bekoff, M. 1977. Canis latrans. Mammalian Species 79: 1-9. https://doi.org/10.2307/3503817

Benson, J.F., and B.R. Patterson. 2013. Moose (Alces alces) predation by eastern coyotes (Canis latrans) and eastern coyote $\times$ eastern wolf (Canis latrans $\times$ Canis lycaon) hybrids. Canadian Journal of Zoology 91: 837841. https://doi.org/10.1139/cjz-2013-0160

Boisjoly, D., J.P. Ouellet, and R. Courtois. 2010. Coyote habitat selection and management implications for the Gaspésie caribou. Journal of Wildlife Management 74: 3-11. https://doi.org/10.2193/2008-149

Bowyer, R.T., S.A. McKenna, and M.E. Shea. 1983. Seasonal changes in coyote food habits as determined by fecal analysis. American Midland Naturalist 109: 266-273. https://doi.org/10.2307/2425406

Bridgland, J., T. Nette, C. Dennis, and D. Quann. 2007. Moose on Cape Breton Island, Nova Scotia: 20th century demographics and emerging issues in the 21st century. Alces 43: 111-121. Accessed 5 March 2020. https:// pdfs.semanticscholar.org/67fd/c73fbd5800fe5ab87f08c 76218352f8cf374.pdf.

Chamrad, A.D., and T.W. Box. 1964. A point frame for sampling rumen contents. Journal of Wildlife Management 28: 473-477. https://doi.org/10.2307/3798199

Dowd, J.L.B., and E.M. Gese. 2012. Seasonal variation of Coyote diet in northwestern Wyoming: implications for dietary overlap with Canada Lynx? Northwest Science
86: 289-299. https://doi.org/10.3955/046.086.0405

Dumond, M., M.A. Villard, and E. Tremblay. 2001. Does coyote diet vary seasonally between a protected and an unprotected forest landscape? Ecoscience 8: 301-310. https://doi.org/10.1080/11956860.2001.11682657

Fedriani, J.M., T.K. Fuller, and R.M. Sauvajot. 2001. Does availability of anthropogenic food enhance densities of omnivorous mammals? An example with coyotes in southern California. Ecography 24: 325-331. https://doi.org/10.1111/j.1600-0587.2001.tb00205.x

Litvaitis, J.A., and D.J. Harrison. 1989. Bobcat-coyote niche relationships during a period of coyote population increase. Canadian Journal of Zoology 67: 1180-1188. https://doi.org/10.1139/z89-170

Lukasik, V.M., and S.M. Alexander. 2011. Human-coyote interactions in Calgary, Alberta. Human Dimensions of Wildlife 16: 114-127. https://doi.org/10.1080/10871209. 2011.544014

Major, J.T., and J.A. Sherburne. 1987. Interspecific relationships of coyotes, bobcats, and red foxes in western Maine. Journal of Wildlife Management 51: 606-616. https://doi.org/10.2307/3801278

Messier, F., and M. Crête. 1985. Moose-wolf dynamics and the natural regulation of moose populations. Oecologia 65: 503-512. https://doi.org/10.1007/ BF00379664

Parker, G.R. 1986. The seasonal diet of Coyotes, Canis latrans, in northern New Brunswick. Canadian FieldNaturalist 100: 74-77. Accessed 5 March 2020. https:// www.biodiversitylibrary.org/page/28072149.

Patterson, B.R., L.K. Benjamin, and F. Messier. 1998. Prey switching and feeding habits of eastern coyotes in relation to snowshoe hare and white-tailed deer densities. Canadian Journal of Zoology 76: 1885-1897. https://doi.org/10.1139/z98-135

Patterson, B.R., and F. Messier. 2000. Factors influencing killing rates of White-tailed Deer by coyotes in eastern Canada. Journal of Wildlife Management 64: 721-732. https://doi.org/10.2307/3802742

Prugh, L.R. 2005. Coyote prey selection and community stability during a decline in food supply. Oikos 110: 253264. https://doi.org/10.1111/j.0030-1299.2005.13478.x

Richer, M.C., M. Crête, J.P. Ouellet, L.P. Rivest, and J. Huot. 2002. The low performance of forest versus rural coyotes in northeastern North America: inequality between presence and availability of prey. Écoscience 9: 44-54. https://doi.org/10.1080/11956860.2002.11682689

Young, S.P., and H.H.T. Jackson. 1951. The Clever Coyote. Stackpole Company, Harrisburg, Pennsylvania, USA.

Received 31 January 2019

Accepted 18 December 2019 